\title{
Inter-annual variability on the water quality in the Lower São Francisco River (NE-Brazil)
}

\author{
Variabilidade inter-anual na qualidade da água no Baixo Rio São Francisco (NE-Brasil)
}

\author{
Paulo Ricardo Petter Medeiros ${ }^{1 *}$, Geórgenes Hilário Cavalcante ${ }^{2}$, \\ Nilva Brandini ${ }^{3}$ and Bastiaan Adriaan Knoppers ${ }^{3}$
}

${ }^{1}$ Programa de Pós-graduação em Geografia, Laboratório de Ciências do Mar, Instituto de Geografia, Desenvolvimento e Meio Ambiente, Universidade Federal de Alagoas - UFAL, CEP 57072-900, Maceió, AL, Brazil

${ }^{2}$ Instituto de Ciências Atmosféricas, Universidade Federal de Alagoas - UFAL, CEP 57072-900, Maceió, AL, Brazil

${ }^{3}$ Departamento de Geoquímica, Instituto de Química, Universidade Federal Fluminense - UFF, CEP 24020-141, Niterói, RJ, Brazil

*e-mail: paulopetter@igdema.ufal.br

Cite as: Medeiros, P.R.P. et al. Inter-annual variability on the water quality in the Lower São Francisco River (NE-Brazil). Acta Limnologica Brasiliensia, 2016, vol. 28, e5.

Abstract: Aim: This study characterized the water quality in the lower São Francisco River (NE-Brazil).This research represents the first work to be carried out in the lower sector of the São Francisco river aiming to quantify and compare limnological variables, during three different years (2001, 2004 and 2007). Methods: Water samples were collected in a transversal section of the river at monthly intervals period on surface layer. Temperature, conductivity, $\mathrm{pH}$, and dissolved oxygen were obtained using a multiparameter probe YSI-6600. The dissolved inorganic nutrients (ammonium, nitrite, nitrate, dissolved phosphorus and silicates), chlorophyll $-a$ and total suspended sediment (TSS) were also determined. Results: The three hydrological years showed differences in precipitation rates and discharge conditions. The year 2001 had precipitation rates below the historical series of rainfall. The mean annual water temperature showed negligible differences among the three years. Dissolved inorganic nutrient concentrations were highest in 2004, with ammonia and nitrate differing statistically between the years $(\mathrm{p}<0.05)$; the later showed the largest concentration of dissolved inorganic nitrogen. Chlorophyll- $a$ showed a slight difference among years. Conclusions: Precipitation intensity has a direct impact on the São Francisco River discharge, but the geographical distribution of the precipitation is also a determinant factor for alterations of the chemical and physical characteristics of the water that reaches the lower sector of the São Francisco River.

Keywords: precipitation; river discharge; nutrients; lower São Francisco River.

Resumo: Objetivo: Este estudo caracterizou a qualidade da água no baixo rio São Francisco (NE-Brasil), sendo o primeiro trabalho realizado no setor inferior do rio São Francisco com o objetivo de quantificar e comparar variáveis limnológicas, durante os anos de 2001, 2004 e 2007. Métodos: Amostras de água foram coletadas em uma seção transversal do rio mensalmente. Temperatura, condutividade, $\mathrm{pH}$, oxigénio dissolvido e foram obtidos utilizando uma sonda YSI 6600-multiparamétrica. Os nutrientes inorgânicos dissolvidos (amônia, nitrito, nitrato, fósforo dissolvido e silicatos), clorofila- $a$ e sedimentos suspensos totais (TSS) foram também determinados. Resultados: Os três anos hidrológicos mostraram diferenças distintas nas taxas de precipitação e condiçóes de descarga. As taxas de precipitação em 2001 estiveram abaixo do nível da série histórica. A temperatura média anual da água mostrou diferenças não significativas entre os três anos. 
Concentraçóes de nutrientes inorgânicos dissolvidos foram mais elevados em 2004, com a amônia e nitrato diferindo estatisticamente entre os anos $(\mathrm{p}<0,05)$. A clorofila- $a$ mostrou pequena diferença entre os anos. Conclusóes: A intensidade da precipitação tem um impacto direto sobre a qualidade da água do baixo São Francisco, entretanto a localização geográfica da precipitação também é um fator determinante para as alteraçóes das características químicas e físicas da água que atinge o setor inferior do rio São Francisco. Precipitações localizadas nas porçóes inferiores da bacia, são mais efetivas no aumento da concentração de nutrientes dissolvidos.

Palavras-chave: precipitação; descarga fluvial; carga de nutrientes; Baixo São Francisco.

\section{Introduction}

Rivers are ecosystems mainly influenced by climatic, geomorphologic and hydrologic regional characteristics (Salomoni et al., 2007). The natural regime of a river is associated with different environmental variables, such as water temperature, sediment accumulation, turbidity, nutrient, dissolved oxygen (Poff et al., 1997). However, anthropogenic impacts resulting from the development associated with population growth, industry, agriculture, water consumption and electricity supply, are the oldest and most significant interventions in the natural systems (Tundisi, 1999).

The physical and chemical characteristics of rivers are highly variable at temporal and spatial scales (Raj \& Azez, 2009). Considering the environmental and economic importance of rivers and their inherent variability, they have been intensely studied throughout the world at local scale (Latrubesse et al., 2005). Although there is an extensive literature about rivers' nature in high and temperate latitudes, data on water quality in tropical rivers remain essentially limited (Latrubesse et al., 2005). In Brazil, limnological studies have been concentrated in major drainage basins (ex. Amazon, Paraná, Tocantins), while studies in medium to small-scale drainage systems are relatively scarce (Necchi et al., 2000, Souza \& Knoppers, 2003).

The São Francisco River has been utilized to several hydropower man-made constructions, water supply, navigation and flood control (Medeiros et al., 2007, 2011a). The most frequent structures are dams, which have considerably altered the hydrologic regime within the lower portion of the river, modifying the water discharges as well as reducing the solid loads downstream (Medeiros et al., 2011a, b). Although extremely important at national and regional levels, due to its multi-purpose water resources, São Francisco river has been relatively poorly studied in regards to the limnological variability, with previous studies only covering periods of one hydrological year or less (Crispim \& Watanabe, 2000, Souza \& Knoppers, 2003, Latrubesse et al., 2005,
Medeiros et al., 2011a, b). To our knowledge there are no limnological studies at inter-annual time scales in this riverine system accessing the impact of climatic and anthropogenic variability in structuring the chemical and physical characteristics. In any aquatic ecosystem, limnological characteristics can affect both fauna and flora (Carmouze, 1994). Therefore, limnological variables are the key parameters when monitoring surface water quality because of their relation to water discharge proprieties, but also because of their effect on the environment. On the basis of in situ observations, we quantify and compare for the first time the limnological variables of the lower São Francisco River sector, over 3hydrological years, including dissolved inorganic nutrients, total suspended sediment and chlorophyll- $a$.

\section{The Study Area}

The São Francisco River hydrographic basin covers $639,219 \mathrm{~km}^{2}$ and is the most extensive basin covering $7.5 \%$ within the Brazilian territory (Figure 1).

The course of the lower São Francisco River begins in a canyon in the relocated blocks of the lower São Francisco Pediplans, extending in the form of waterfalls in a rocky gravel bed for $100 \mathrm{~km}$, until the city of Pão de Açúcar (AL). From Páo de Açúcar up to the mouth of the River, about $165 \mathrm{~km}$, the declivity of the channel is reduced. The fluvial-marine plains of the lower São Francisco stretch from Penedo's city (AL) to the coast, including Pleistocene marine terraces, and are surrounded by the Tertiary tablelands base (Dominguez, 1996).

The climate in the São Francisco basin is warm, with the semi-arid area upstream, undergoing a transition to sub-humid in the middle course, and then to humid, close to the coastal zone. Precipitation is the main phenomena characterizing the climatic variations in the area (Bernardes, 1951). The rainfall distribution in the upper São Francisco and in the upper part of the middle is responsible for $75 \%$ of the discharge of the river reaching the coast. 


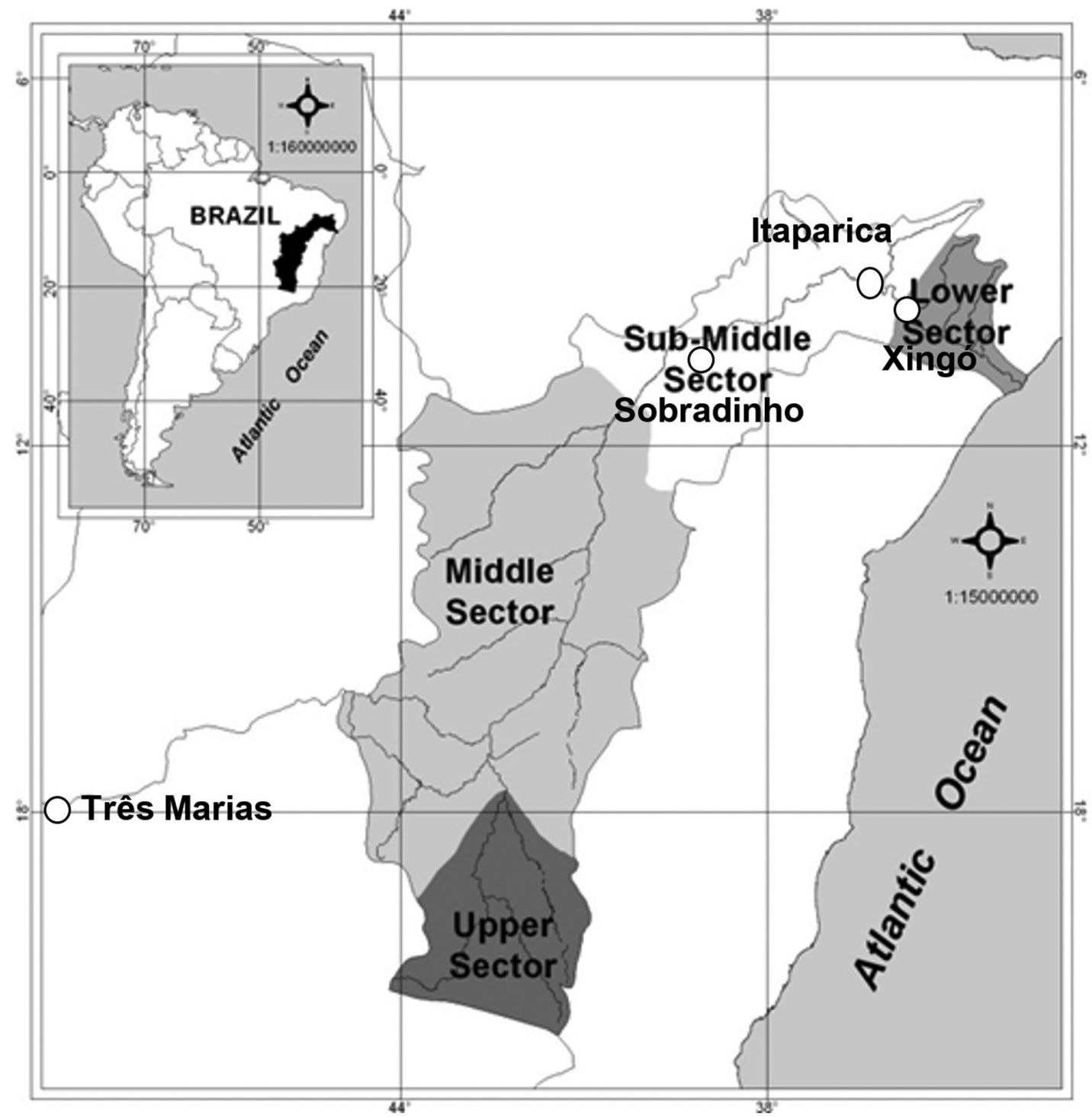

Figure 1. The São Francisco River hydrographic basin.

In comparison, the climate in the middle-lower and lower São Francisco is very dry and presents a different seasonal rainfall distribution (Bernardes, 1951).

\section{Materials and Methods}

Water samples were collected in a transversal section of the river $(-700 \mathrm{~m}$ width) located at S 10¹2'43.6"; W 3649'14" (Figure 2). Monthly surface water samples were collected during 2001, 2004 and 2007, using a Van Dorn bottle. The number of samples collected ranged from 2 to 4 , due to the variation of the length of the wetted perimeter. This variation occurred because at the peak water discharge period there is an increase in the rivers wetted perimeter. The environmental parameters of temperature, conductivity, $\mathrm{pH}$, and dissolved oxygen were obtained using a multiparameter probe YSI-6600. Ammonium, nitrite, nitrate, dissolved phosphorus and silicates were determined according to Carmouze (1994). Chlorophyll- $a$ and total suspended sediment (TSS) were estimated according to Strickland \& Parsons (1972).

The software Statistic 8 was used to process and run non-parametric Spearman analysis throughout the time series, and principal component analysis (PCA) to evaluate the data variability and to identify the factors responsible for the variability (Mazlum et al., 1999). Prior to analyses, the PCA results were normalized by using a correlation matrix to account for different scales and units. The main components identified by correlation matrix procedure were subsequently selected in 
terms of percentage of variance explained by the variable, keeping only the values with at least 50\% of variance explained.

\section{Results}

\subsection{Precipitation and river discharge}

The three hydrological years showed differences in precipitation rates and discharge conditions. Precipitation rates in 2001 were below the historical series of rainfall (Figure 3a), resulting in critical water levels in the hydropower reservoirs. Conversely, higher precipitation rates observed in January and February of 2004 and 2007 were above the historical series of rainfall (Figure 3a). Similar pattern of variation on the water discharge was observed for 2004 and 2007 and, low range of the values was a characteristics for 2001 (Figure 3b). The monthly-average river discharges in 2001 were lower than the ones for 2004 and 2007 with the exception of March (Figure 3b). Annual average discharge in $2004\left(1,970 \mathrm{~m}^{3} / \mathrm{s} \pm 516 \mathrm{~m}^{3} / \mathrm{s}\right)$ was higher than $2001\left(1,496 \mathrm{~m}^{3} / \mathrm{s} \pm 373 \mathrm{~m}^{3} / \mathrm{s}\right)$, but lower than $2007\left(2,808 \mathrm{~m}^{3} / \mathrm{s} \pm 1,177 \mathrm{~m}^{3} / \mathrm{s}\right)$ (Figure 3b).

\subsection{Environmental variables}

The mean annual water temperature showed negligible differences among the three years $\left(27.21^{\circ} \mathrm{C} \pm 0.76^{\circ} \mathrm{C}, 26.79^{\circ} \mathrm{C} \pm 1.10^{\circ} \mathrm{C}\right.$ and $27.9^{\circ} \mathrm{C} \pm 1.47^{\circ} \mathrm{C}$, for 2001,2004 and 2007 , respectively $(\mathrm{p}<0.05)$, which are typical values of
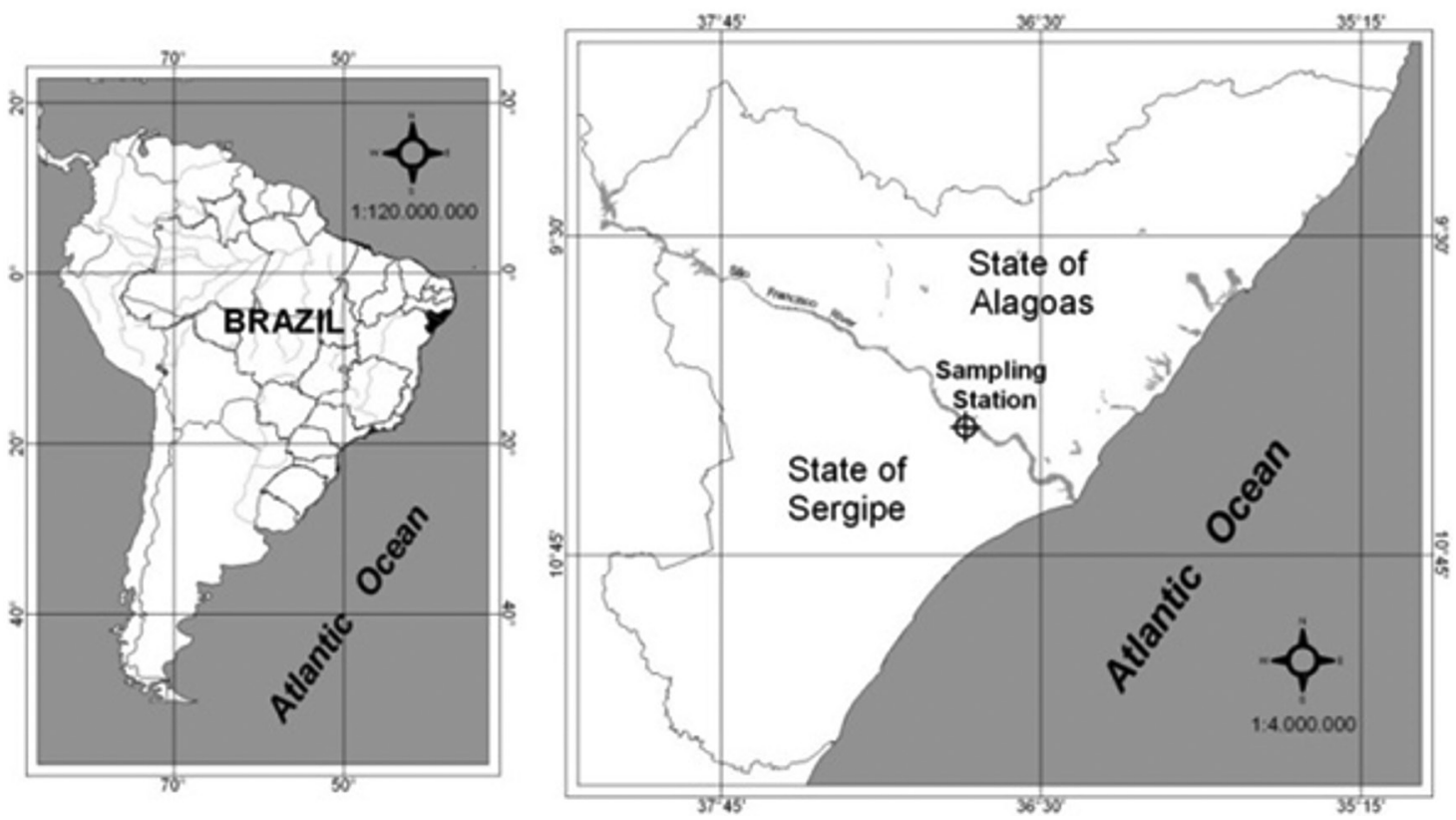

Figure 2. Location of the study area and sampling stations in the lower sector of the São Francisco River.
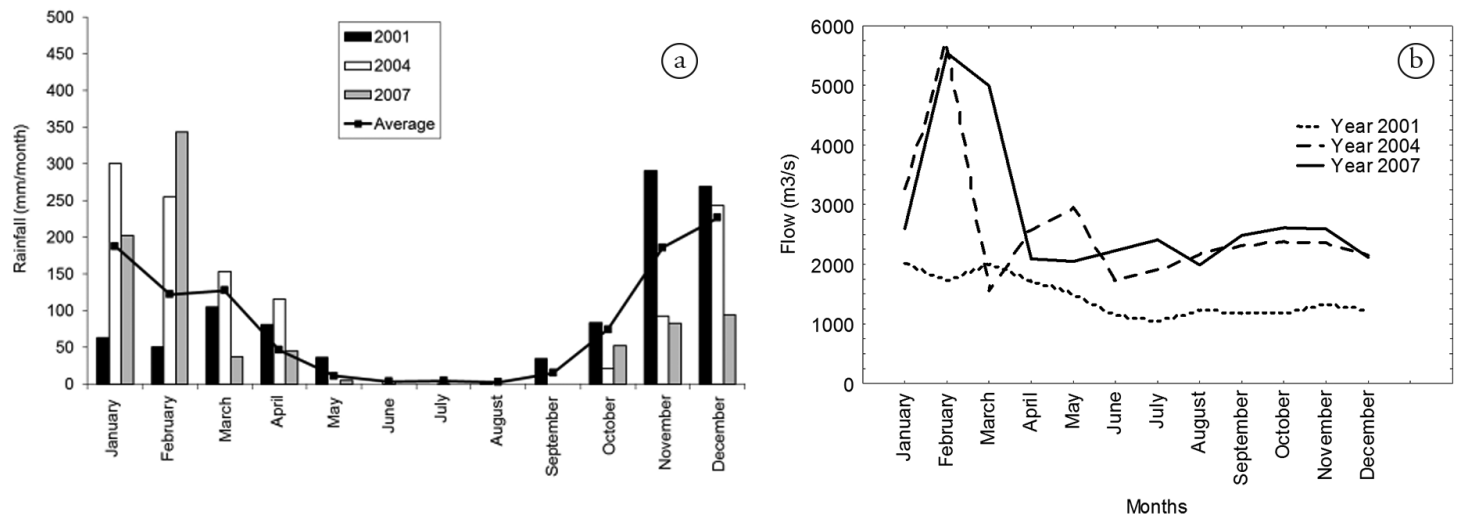

Figure 3. Monthly precipitation rates during the study period of the São Francisco River (a); Monthly discharges in the lower São Francisco River sector (b). Continues line in (a) indicates the historical precipitation average. Source ANA (2008). 
tropical aquatic environments (Meybeck \& Ragu, 1996). Mean annual $\mathrm{pH}$ differed among the years with slightly higher $\mathrm{pH}$ in 2007 (7.64 \pm 0.15 ; $\mathrm{p}<0.05)$, followed closely by $2004(7.25 \pm 0.50)$ and 2001 (7.45 \pm 0.48$)$. The São Francisco surface water showed oxygen levels greater than $6.0 \mathrm{mg} \cdot \mathrm{L}^{-1}$ throughout the years, in some measurements reaching supersaturation levels of $8.2 \mathrm{mg} . \mathrm{L}^{-1}$ in 2004 $(\mathrm{p}<0.05)$. The dissolved oxygen concentrations are similar to those found by Silva et al. $(2009,2010)$ for other regions of the hydrographic basin.

Electrical conductivity significantly differed among the observed years (Figure 4). In contrast to the years 2004 and 2007, lowest values (Table 1) were observed in 2001 (Figure $4 a ; p<0.05$ ). The year 2004 showed the highest mean and annual variability of electrical conductivity $\left(113.28 \pm 51.75 \mu \mathrm{S} . \mathrm{cm}^{-1}\right)$. This can was due to the higher mean monthly electrical conductivity for January, February and March in $2004\left(242.5 \mu \mathrm{S} . \mathrm{cm}^{-1} ; 183.6 \mu \mathrm{S} . \mathrm{cm}^{-1}\right.$; $117.45 \mu \mathrm{S} . \mathrm{cm}^{-1}$, respectively) compared to the other years (Figure $4 \mathrm{~b}$ ). Similar values of electrical conductivity were found by Silva et al. (2009, 2010).

Total suspended sediments (TSS) showed largest mean in 2004 (Figure 5a). This value was
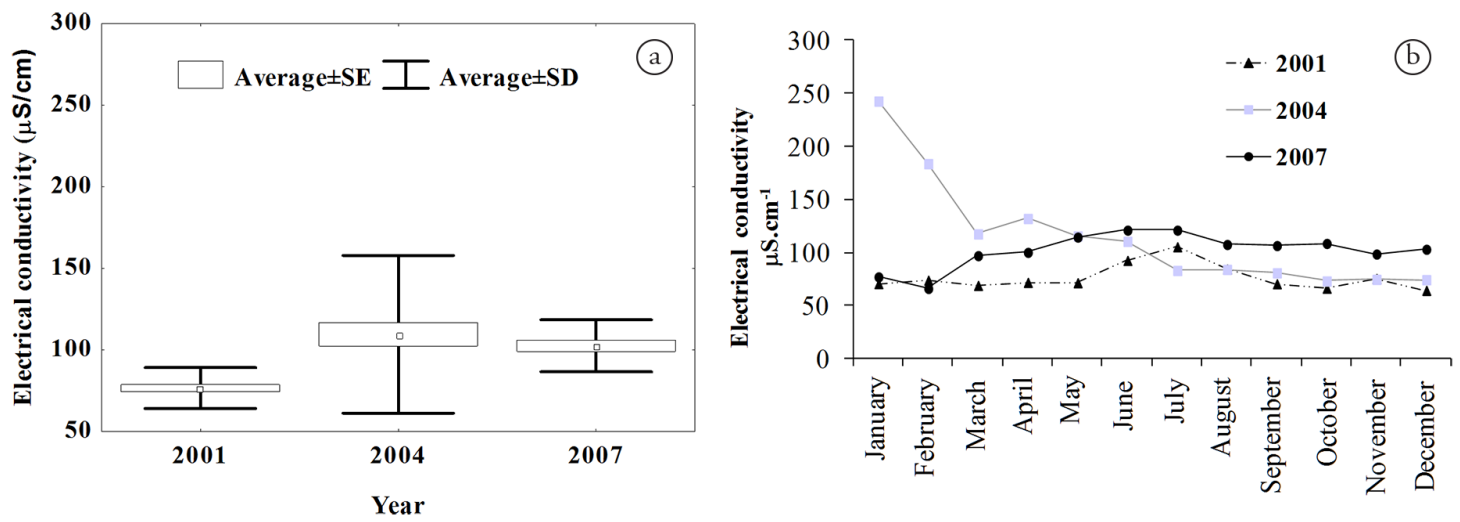

Figure 4. Inter-annual variability on the means and standard-deviations (a) and on the monthly variation (b) of the electrical conductivity during the three hydrological years.

Table 1. Means and standard deviations of inorganic dissolved nutrients, chlorophyll- $a$, and electrical conductivity during the three hydrological years.

\begin{tabular}{|c|c|c|c|}
\hline Variable & 2001 & 2004 & 2007 \\
\hline $\mathrm{N}-\mathrm{NH}_{4}\left(\mu \mathrm{g} \mathrm{L}^{-1}\right)$ & $29.92 \pm 32.82$ & $46.25 \pm 39.69$ & $10.2 \pm 8.31$ \\
\hline $\mathrm{N}-\mathrm{NO}_{2}\left(\mu \mathrm{g} \mathrm{L}^{-1}\right)$ & $1.17 \pm 1.12$ & $6.56 \pm 3.84$ & $2.89 \pm 1.94$ \\
\hline $\mathrm{N}-\mathrm{NO}_{3}\left(\mu \mathrm{g} \mathrm{L}^{-1}\right)$ & $66.13 \pm 60.63$ & $181.57 \pm 166.61$ & $44.16 \pm 68.70$ \\
\hline $\mathrm{P}^{-} \mathrm{PO}_{4}\left(\mu \mathrm{g} \mathrm{L}^{-1}\right)$ & $4.70 \pm 4.88$ & $381.93 \pm 312.35$ & $5.29 \pm 3.29$ \\
\hline $\mathrm{Si}^{-\mathrm{SiO}_{4}}\left(\mathrm{mg} \mathrm{L}^{-1}\right)$ & $10.3 \pm 3.06$ & $3.79 \pm 0.85$ & $2.48 \pm 1.29$ \\
\hline $\mathrm{Cl}-a\left(\mu \mathrm{g} \mathrm{L}^{-1}\right)$ & $1.55 \pm 1.12$ & $1.68 \pm 1.62$ & $1.26 \pm 0.87$ \\
\hline E. conductivity $\left(\mu \mathrm{S} \mathrm{cm}^{-1}\right)$ & $76.31 \pm 11.99$ & $114.28 \pm 51.75$ & $101.72 \pm 16.30$ \\
\hline
\end{tabular}
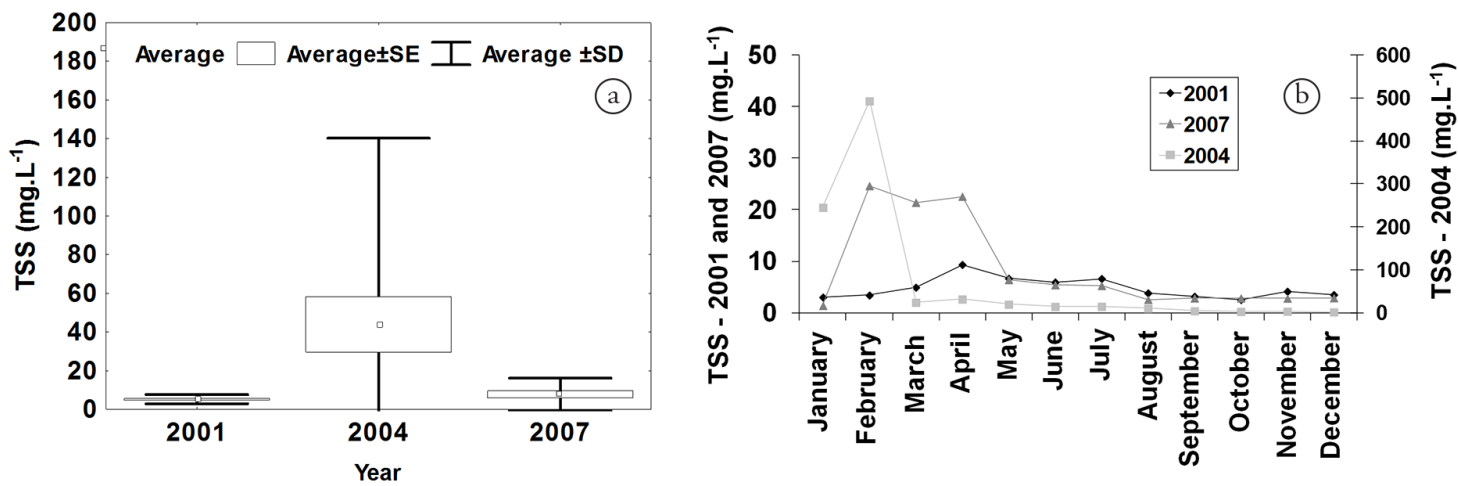

Figure 5. Inter-annual variability on the means and standard-deviations (a) and on the monthly variation (b) of TSS (total suspended sediment) during the three hydrological years. 
due to the high concentrations recorded in January (270 mg.L $\mathrm{L}^{-1}$ ) and February (500 mg.L. $\mathrm{L}^{-1}$ ) (Figure 5b), when river discharge "peaked" (Figure $3 \mathrm{~b}$ ). The TSS values from January to March 2007 revealed pattern similar to the ones observed in 2004 (Figure 5b), suggesting an influence of the precipitation during this year (Figure 3a).

\subsection{Inorganic nutrients and chlorophyll-a}

Annual means of dissolved inorganic nutrient concentrations were highest in 2004. Ammonia and nitrate differed significantly $(\mathrm{p}<0.05)$ among the years (Table 1). In contrast, nitrite showed the lowest annual mean in 2001 (Table 1). The annual mean of phosphorus concentration was similar during 2001 and 2007, differing significantly in 2004 (Table 1). Silicate showed a decreasing trend from 2001 to 2007. Chlorophyll- $a$ showed a slight difference among years (Table 1).

The difference in the chemical and physical water characteristics throughout the lower São Francisco can be seen in the correlation analysis between nitrogen compounds and total suspended sediment (Table 2). All the correlation coefficients were significant in the three years, except between ammonium and TSS in 2001 and 2007 (Table 2).

Strong differences in correlation coefficients between chlorophyll- $a$ and the nutrients were detected among the years (Table 3). Significant correlations between both nitrite and nitrate

Table 2. Spearman's nonparametric correlation among nitrogen nutrients and TSS during the three hydrological years $(*$ significant at $\mathrm{p}<0.05)$.

\begin{tabular}{cccc}
\hline Variable/Year & 2001 & $\mathbf{2 0 0 4}$ & $\mathbf{2 0 0 7}$ \\
\hline $\mathrm{N}-\mathrm{NH}_{4}$ & 0.251748 & ${ }^{*} \mathbf{0 . 8 8 1 1 1 9}$ & -0.115587 \\
$\mathrm{~N}-\mathrm{NO}_{2}$ & ${ }^{*} \mathbf{0 . 7 1 9 6 0 5}$ & ${ }^{*} \mathbf{0 . 8 8 6 1 6 6}$ & ${ }^{*} \mathbf{0 . 7 2 7 2 7 3}$ \\
$\mathrm{N}_{\mathrm{NO}}$ & ${ }_{3} \mathbf{0 . 7 4 8 2 5 2}$ & ${ }^{*} \mathbf{0 . 8 8 1 1 1 9}$ & ${ }^{*} \mathbf{0 . 7 3 4 2 6 6}$ \\
\hline
\end{tabular}

with chlorophyll- $a$ were found in 2001. In 2004, no correlations between the nutrients and the chlorophyll- $a$ were recorded and, in 2007 only nitrate was correlated with chlorophyll- $a$.

The annual flows, calculated from the monthly average values of flow rates, also show differences between the years studied. The year 2001 presented annual flow of $45 \mathrm{~km}^{3} /$ year, while the years 2004 and 2007 had higher annual flows, with respectively 81 and $86 \mathrm{~km}^{3} /$ year. Although in 2004, a greater rainfall (except the lower sector) was observed considering each sector of the basin (Table 4), lower annual flow was recorded. This suggests the effect of water storage in reservoirs and management of flow with hydroelectric energy production purposes.

The principal component analysis revealed that the two first components at first axis explained $55.66 \%$ of the variance (Figure 6). The first factor grouped inorganic nutrients (except silicate), TSS, turbidity and conductivity. The high negative factors of turbidity and TSS are indicative of a dry period or precipitation reduction. The positive factor of silicate can be attributed to the runoff during low precipitation rates and river discharge (Figure 6).

\section{4. $N: P$ ratio}

The monthly variability of N:P was attributed to the fluctuation of phosphate concentrations (Figure 7). In 2004, the high phosphate concentrations compared with those of nitrogen produced N:P ratios (less than 1, except in December), lower than the Redfield ratio (16N:1P). Conversely, the N:P ratios in 2001 presented values above the Redfield in the major part of the year while in 2007 there was no significant change in $\mathrm{N}: \mathrm{P}$ ratio.

Table 3. Spearman's nonparametric correlation among nutrients and Chlorophyll- $a$ in the three hydrological years (*significant at $\mathrm{p}<0.05)$.

\begin{tabular}{ccccc}
\hline Year/Nutrient & $\mathrm{N}-\mathrm{NH}_{4}$ & $\mathrm{~N}-\mathrm{NO}_{2}$ & $\mathrm{~N}-\mathrm{NO}_{3}$ & $\mathbf{P}_{\mathbf{2}} \mathbf{P O}_{4}$ \\
\hline Year 2001 & 0.048951 & ${ }^{*} \mathbf{0 . 7 7 6 0 4 4}$ & ${ }^{*} \mathbf{0 . 7 7 6 2 2 4}$ & -0.454545 \\
Year 2004 & -0.447552 & $-\mathbf{0 . 2 5 9 1 9 5}$ & $\mathbf{- 0 . 1 6 0 8 3 9}$ & -0.314685 \\
Year 2007 & -0.173990 & $\mathbf{0 . 3 1 5 7 9 1}$ & ${ }^{*} \mathbf{0 . 6 1 4 0 3 9}$ & 0.551056 \\
\hline
\end{tabular}

Table 4. Accumulated rainfall (mm) for physiographic sector of the São Francisco (Medeiros et al., 2015).

\begin{tabular}{ccccc}
\hline Year & Upper $(\mathbf{m m})$ & Middle $(\mathbf{m m})$ & Sub-middle $(\mathbf{m m})$ & Lower $(\mathbf{m m})$ \\
\hline Ano 2001 & $1,014.00$ & 658.00 & 264.00 & 399.40 \\
Ano 2004 & $1,185.30$ & 873.70 & 708.00 & 309.80 \\
Ano 2007 & 862.70 & 753.30 & 309.80 & 581.60 \\
\hline
\end{tabular}




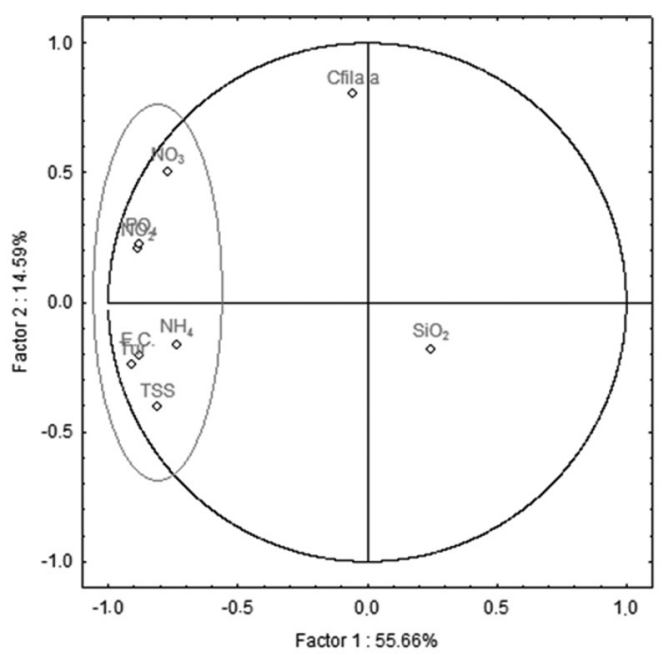

\begin{tabular}{lcc}
\hline Variables & Factor 1 & Factor 2 \\
\hline Ammonium $\left(\mathrm{NH}_{4}\right)$ & -0.74 & -0.16 \\
Nitrite $\left(\mathrm{NO}_{2}\right)$ & -0.89 & 0.21 \\
Nitrate $\left(\mathrm{NO}_{3}\right)$ & -0.77 & 0.50 \\
Phosphate $\left(\mathrm{PO}_{4}\right)$ & -0.88 & 0.22 \\
Chlorophyll- $a(\mathrm{Chl}-a)$ & -0.05 & 0.80 \\
Silicate $\left(\mathrm{SiO}_{2}\right)$ & 0.25 & -0.18 \\
Total Solids Suspension (TSS) & -0.81 & -0.41 \\
Turbidity (Tur) & -0.91 & -0.24 \\
Electrical conductivity (E.C.) & -0.88 & -0.21 \\
\hline
\end{tabular}

Figure 6. Ordination of the data from PCA analysis based on limnological variables, inorganic dissolved nutrients, chlorophyll- $a$ and TSS (total suspended sediment).

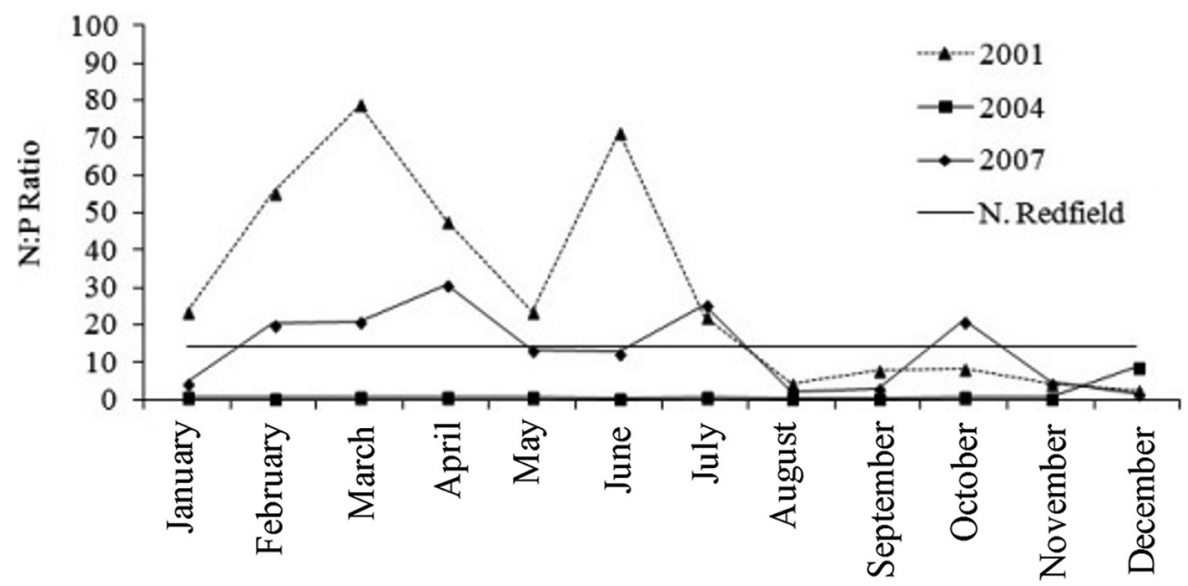

Figure 7. Monthly variability of N:P ratio during the three hydrological years.

\section{Discussion}

Precipitation and water run-off effects on nutrients loads and total suspended sediment in the lower São Francisco river have been previously studied (e.g., Medeiros et al. 2011a, b), but many questions still remain about how historically the lower São Francisco river ecosystem will respond to long-term dam cascade constructed along its middle-lower semi-arid river course. The changes in nitrogen nutrients reported herein reflect responses to water run-off by the limnological variables and chlorophyll- $a$ that drive key geochemical reactions. Inorganic nutrients exchange measurements provide process-related insights into responses to environmental stress and do so in a way that integrates important components of the ecosystem (water and soils) under naturally variable environmental conditions (Childers et al., 1993; Weston et al. 2011).

Our results show that there is no simple and general relationship between precipitation, water discharge, and limnological variables including dissolved inorganic nutrients and chlorophyll- $a$ for the river system at present. The reason for this result is mainly due to the complexity of the river system, where the water originates from multiple sectors of the river with precipitation strongly varying in time and space (Tucci, 2000). The river regulation by hydropower and the lake formed by the Xingó Dam acts as a huge detention storage, obscuring the dependencies between variables (Graf, 2006; Manyari \& Carvalho Júnior, 2007; Coelho, 2008). Precipitations in the upper and middle sectors of the São Francisco River have mostly an indirect impact on the flow in the river through the runoff 
to the lower São Francisco River (Rocha et al., 2013). Most of the river flow downstream from the Xingó Dam lake (Figure 1) originates not only from the rainfall generated at the headwaters of the basin (Tucci, 2000), but also the rainfall that occurs within the middle-lower and lower São Francisco River sectors.

Taking into consideration the electrical conductivity of water in the response of river discharge to precipitation, the hydrologic year of 2004 revealed the highest water conductivity despite the lower annual mean discharge compared to 2007. Analyses of accumulate precipitation in the middle-lower and lower São Francisco River, indicated that heavy rainfall concentrated in the months of January and February had a large impact on the lixiviation and surface runoff throughout saline soil areas located in these regions (Bernardes, 1951). As a result, there was an increase in the ionic contribution reflected by the electrical conductivity. Under conditions where precipitation was distributed in the upper and middle river basin sectors, such as in 2007, lixiviation by surface runoff was likely reduced, contributing to the decrease of electrical conductivity regardless of flow conditions (Randall \& Mulla, 2001).

The year 2007 showed the highest average $\mathrm{pH}$ which was attributed to the intense precipitation rates generating strong lixiviation and, as consequence, more hydroxides were carried out downstream. The monthly average $\mathrm{pH}$ ranged from 6 to 8, typical values of continental water bodies (Esteves, 1998). The lack of Spearman correlation $(\mathrm{p}<0.05)$ between $\mathrm{pH}$ and chlorophyll- $a$ revealed no influence of photosynthetic phytoplankton activity in the $\mathrm{pH}$ variability. Similarly, dissolved oxygen showed no significant Spearman correlation, suggesting that biological processes from photosynthesis or breathing did not influence such results, which is characteristic of oligotrophic environment (Goldman \& Horne, 1983). The sewage discharges from several cities along the river also indicated no influence on reducing the dissolved oxygen concentration, revealing a high dilution capacity within the river system. The dissolved oxygen net balance was therefore influenced by physical factors such as winds and internal diffusion rather than biological and anthropogenic factors.

Transport of nutrients, especially nitrate-nitrogen in surface waters is highly influenced by climatic variables and soil proprieties, and surface runoff which in turn are modified by the temporal precipitation pattern (Randall \& Mulla, 2001).
In the São Francisco basin the precipitation originated in multiple sectors of its hydrographic basin resulted in different chemical and physical water characteristics shown by the strong correlation among nutrients and suspended-particulate matter. The year 2004 differ from the years 2001 and 2007 in regards to the precipitation rates distributed throughout the several sectors of the river, and more intensely in the middle and lower São Francisco sectors. The resultant effect was more nutrient loads carried out into the river due to the intense precipitation in a semi-arid region, where soils are very shallow and the crystalline basement are near the surface, which difficult the water infiltration but increase erosion and lixiviation. Similarly, the intense surface runoff in 2004 was also responsible for the high nitrogen concentrations.

Compared to rivers, reservoirs often act as a sink of nitrogen and phosphorus due to the enhancement of sedimentation and the residence time of stored water (Bosch \& Allan, 2008). In the case of the dam cascade and its reservoirs, each dam eliminates part of the nutrients and TSS resulting in a progressive reduction of phosphorus and nitrogen concentrations (Tundisi \& Matsumura-Tundisi, 2008). Considering that in 2004 the precipitation rates were concentrated at the final lower end portion of the dam cascade (January and February), it played a small role on retaining the river discharge and TSS, resulting in high nutrient concentrations. The geographical location of the precipitation also had a large impact on the lixiviation and surface runoff through saline soil areas located in this semi-arid region. The high correlations between nitrogen and TSS corroborate the small retention and the nutrients origin associated with surface runoff. Conversely, the nutrients reduction in 2007 was attributed to the dam cascade system responsible for retaining the surface runoff in the upper and middle sector of the river.

The influence of the geographical location of precipitation and surface runoff on the dissolved inorganic nitrogen was also present in the phosphate. The TSS are the main transporter of phosphate, processes that result in TSS deposition, will reduce the phosphate available in the environment. Such behavior was observed specially in 2007 where the dams retained most of the material in the upper sectors of the river, as reflected by the lower phosphate values found in the São Francisco River, in contract to phosphate concentrations in 2004. The lack of correlation between phosphate and TSS also corroborate our findings. Different from other 
tropical rivers (Kattan et al., 1987), the lower São Francisco River showed no delay between maximum TSS and maximum river discharges. This behavior suggests predominance of erosion processes due to runoff and small sediment remobilization on the bottom layers.

There were substantial differences in the biochemical mechanisms important in modifying silica characteristics along the three years. In the year 2001, the lowest discharge rates were found, and therefore the surface runoff was possibly more significant together with groundwater discharge to generate the silica loads compared to the other years. However, the reduction of silica in the years 2004 and 2007 was also attributed to the intense water discharges diluting the silica towards the lower sector of the river.

Comparing ammonium and nitrate concentrations with other tropical rivers (Table 5) the similarities of the values become evident. On the other hand, nitrate showed a much lower concentration trend than the reference values.

Chlorophyll-a concentrations found in the São Francisco River are lower than the other rivers located in tropical aquatic environments (Table 6), indicating oligotrophic characteristics. The concentrations are similar to those found by Lima \& Severi (2014). The correlation coefficient between chlorophyll- $a$ and the other variables revealed statistical significance only with nitrite (0.78) in 2001, and nitrate with 0.78 and 0.61 in 2001 and 2007, respectively $(\mathrm{p}<0.05)$, suggesting phytoplankton growth limitation by nitrogen.

The variability of chemical water properties and the N:P ratio can be an important evidence in determining the abundance rate and composition of the periodic and geographical distribution of phytoplankton (Hecky \& Kilham, 1988). In natural phytoplankton communities several species are present at the same time, representing a large demand of nitrogen and phosphorus. The monthly variation of the $\mathrm{N}: \mathrm{P}$ ratio among the years was mainly attributed to the variability in phosphorus. The year 2004 presented higher phosphorus concentrations compared to nitrogen. Therefore the year 2004 revealed intense lixiviation by nitrogen as indicated by the very small N:P ratio (less than 1 , except in December), much less than the Redfield

Table 5. Annual mean concentration of inorganic dissolved nutrients during the three hydrological year and comparison with the values from other tropical rivers (*from Meybeck \& Ragu, 1996).

\begin{tabular}{lcccc}
\hline \multicolumn{1}{c}{ River (country) } & $\mathbf{N H}_{4}\left(\boldsymbol{\mu g ~ \mathbf { ~ L } ^ { - 1 }}\right)$ & $\mathbf{N O}_{3}\left(\mu \mathbf{g ~ L}^{-1}\right)$ & $\mathbf{P}_{-} \mathbf{P O}_{4}\left(\mu \mathbf{g ~ L}^{-1}\right)$ & $\mathbf{S i}_{-} \mathbf{S i O}_{2}\left(\mathbf{m g ~ L}^{-1}\right)$ \\
\hline Amazonas (Brazil) & 20 & 140 & 22 & 6.9 \\
Colorado* (United States) & - & 350 & - & - \\
Danúbi* (Romania) & - & 1800 & - & - \\
Delaware*(United States) & 30 & 1000 & - & - \\
Ebro*(Span) & - & 1500 & - & - \\
Madalena* (Colombia) & 40 & 250 & 120 & 6.3 \\
Orinonoco* (Venezuela) & 35 & 80 & 10 & 13.8 \\
Purar* (New Guinea) & - & 40 & 2 & 11.6 \\
Tocantins* (Brazil) & - & 150 & 3 & - \\
Zaire* (Zaire) & - & 90 & 24 & 16.8 \\
Zambez* (Mozambique) & - & 130 & 10 & 10.3 \\
São Francisco River-2001 & 29.92 & 66.13 & 4.7 & 3.79 \\
São Francisco River-2004 & 46.25 & 181.57 & 381.93 & 2.48 \\
São Francisco River-2007 & 10.2 & 44.16 & 5.29 & \\
\hline
\end{tabular}

Table 6. Comparison on the values of chlorophyll-a from aquatic tropical Brazilian environments and from São Francisco River.

\begin{tabular}{ll}
\hline \multicolumn{1}{c}{ Estuary/River } & \multicolumn{1}{c}{ Chlorophyll-a $\boldsymbol{\mu g}$ /L (mean; minimum - maximum) } \\
\hline Perequê River Estuary (SC, Brazil) & \multicolumn{1}{c}{$(2.25 ; 0.76-3.34)$} \\
Pisa Sal River Estuary (RN, Brazil) $)^{2}$ & $(12.6)$ \\
GolfãoMaranhense (MA, Brazil) ${ }^{3}$ & $(1.92-72.3)$ \\
São Francisco River - 2001 & $(1.55 ; 0.34-2.77)$ \\
São Francisco River - 2004 & $(1.68 ; 0.4-6.4)$ \\
São Francisco River - 2007 & $(1.26 ; 0.5-3.84)$ \\
São Francisco River $-2007-2008^{4}$ & $(0.1-1.76)$ \\
\hline
\end{tabular}

${ }^{1}$ Signorim et al. (2010); ${ }^{2}$ Santiago et al. (2005); ${ }^{3}$ Azevedo et al. (2008); ${ }^{4}$ Lima \& Severi (2014). 
ration (16N:1P). In contrast, the year 2001 showed $\mathrm{N}: \mathrm{P}$ ratio above 16:1 for the first seven months, as indicative of phosphorus limitation, where after this period the increasing of phosphorus concentration is reflected in the reduction of $\mathrm{N}: \mathrm{P}$ ratio, again bringing the nitrogen as the main environmental factor. Considering the year 2007, there was no predominant trend in the N:P ratio reflecting similar behavior as the year 2004 where the water discharge generated mainly in the lower portion of the river, modified the $\mathrm{N}: \mathrm{P}$ ratio, making the environment nitrogen dependent.

\section{Acknowledgements}

$\mathrm{CNPq}$ for the support provided through the projects Instituto do Milênio Estuários CNPq/ MCT Proc. No. 420.050/2005-1 and CNPq INCT-TMC Ocean Proc. No. 573.601/2008-9.

\section{References}

AGÊNCIA NACIONAL DAS ÁGUAS - ANA. [online]. Brasília: ANA, 2008. [viewed 16 July 2012]. Available from: http://www.ana.gov.br

AZEVEDO, A.C.G., FEITOSA, F.A.N. and KOENING, M.L. Distribuição espacial e temporal da biomassa fitoplanctônica e variáveis ambientais no Golfấo Maranhense, Brasil. Acta Botanica Brasílica, 2008, 22(3), 870-877. http://dx.doi.org/10.1590/ S0102-33062008000300022.

BERNARDES, L.M.C. Notas sobre o clima da bacia do Rio São Francisco. Revista Brasileira de Geografia, 1951, 13(3), 473-489.

BOSCH, N.S. and ALLAN, J.D. The influence of impoundments on nutrient budgets in two catchments of Southeastern Michigan. Biogeochemistry, 2008, 87(3), 325-338. http://dx.doi.org/10.1007/s10533008-9187-6.

CARMOUZE, J.P. O metabolismo de ecossistemas aquáticos. São Paulo: Edgard Blucher/FAPESP, 1994.

CHILDERS, D.L., SKLAR, F.H., DRAKE, B. and JORDAN, T. Seasonal measurements of sediment elevation in three mid-Atlantic estuaries. Journal of Coastal Research, 1993, 9, 986-1003.

COELHO, A.L.N. Geomorfologia fluvial de rios impactados por barragens. Caminhos de Geografia, 2008, 9, 16-32.

CRISPIM, M.C. and WATANABE, T. Caracterização limnológica das bacias doadoras e receptoras de águas do Rio São Francisco: 1- Zooplâncton. Acta Limnologica Brasiliensia, 2000, 1, 93-103.

DOMINGUEZ, J.M.L. The São Francisco Strandplain: a paradigm for wavedominate deltas. In M. De Batist and P. Jacobs, eds. Geology of siliclastic shelf seas. London: Geological Society, 1996, p. 117, 217-232.
ESTEVES, F.A. Fundamentos de limnologia. Rio de Janeiro: Ed. Interciencia, 1998, p. 226.

GOLDMAN, R.C. and HORNE, A.J. Limnology. Tokyo: McGraw-Hill, 1983, p. 464.

GRAF, W.L. Downstream hydrologic and geomorphic effects of large dams on american rivers. Geomorphology, 2006, 79(3-4), 336-360. http:// dx.doi.org/10.1016/j.geomorph.2006.06.022.

HECKY, R.E. and KILHAM, P. Nutrient limitation of phytoplankton in freshwater and marine environments: A review of recent evidence on the effects of enrichment. Limnology and Oceanography, 1988, 33(4_part_2), 196-822. http://dx.doi. org/10.4319/lo.1988.33.4_part_2.0796.

KATTAN, Z., GAC, J.Y. and PROBST, J.L. Suspended sediment load and mechanical erosion in the Senegal basin: Estimation of the surface runoff concentration and relative contribution of channel and slope erosion. Journal of Hydrology, 1987, 92(1-2), 59-76. http://dx.doi.org/10.1016/0022-1694(87)90089-8.

LATRUBESSE, E.M., STEVEAUX, J.C. and SINHÁ, R. Tropical River. Geomorphology, 2005, 70(3-4), 187-206. http://dx.doi.org/10.1016/j. geomorph.2005.02.005.

LIMA, A.E. and SEVERI, W. Estado trófico na cascata de reservatórios de um rio no semiárido brasileiro. Agrária - Revista Brasileira de Ciências Agrárias, 2014, 9(1), 124-133.

MANYARI, W.V. and CARVALHO JÚNIOR, A.O. Environmental considerations in energy planning for the Amazon region: Downstream effects of dams. Energy Policy, 2007, 35(12), 6526-6534. http:// dx.doi.org/10.1016/j.enpol.2007.07.031.

MAZLUM, N., OZER, A. and MAZLUM, S. Interpretation of water quality data by principal component analysis. Turkish Journal of Engineering and Environmental Science, 1999, 23, 19-26.

MEDEIROS, P.R.P., KNOPPERS, B.A., SANTOS JUNIOR, R.C. and SOUZA, W.F.L. Aporte do material em suspensão e sua dispersão na Zona Costeira do Rio São Francisco (SE/AL). Geoquimica Brasiliensis, 2007, 21(2), 209-228.

MEDEIROS, P.R.P., KNOPPERS, B., SOUZA, W.F.L. and OLIVEIRA, E.N. Aporte de material em suspensão no baixo Rio São Francisco (SE/AL), em diferentes condiçôes hidrológicas. Brazilian Journal Aquatic Science and Technology, 2011a, 15(1), 42-53. http://dx.doi.org/10.14210/bjast.v15n1.p42-53.

MEDEIROS, P.R.P., KNOPPERS, B.A., CAVALCANTE, G.H. and SOUZA, W.F.L. Changes in nutrients loads (N, P, Si) in the São Francisco Estuary after the constructions of dams. Brazilian Archives of Biology and Technology, 2011b, 54(2), 387-397. http://dx.doi.org/10.1590/S151689132011000200022 . 
MEDEIROS, P.R.P., SEGUNDO, C.G.H. AND MELO-MAGALHÃES, E.M. Comportamento da turbidez e material em suspensão em um rio com vazão regularizada por sistema de barragens em cascata: Rio São Francisco (NE, Brasil). Geochimicha Brasiliensis, 2015, 29, 35-44.

MEYBECK, M. and RAGU, A. River Discharges to the Oceans: an assessment of suspended solids, major ions, and nutrients. Nairobi: UNEP, 1996, p. 250. Environment Information and Assessment Report.

NECCHI, O., BRANCO, L.H.Z. and BRANCO, C.C.Z. Características limnológicas da bacia do Alto São Francisco, Parque Nacional da Serra da Canastra, Minas Gerais. Acta Limnologica Brasiliensia, 2000, $12,11-22$.

POFF, N.L., ALLAN, J.D., BAIN, M.B., KARR, J.R., PRESTEGAARD, K.L., RICHTER, B.D., SPARKS, R.E. and STROMBERG, J.C. The natural flow regime: a paradigm for river conservation and restoration. Bioscience, 1997, 47(11), 769-784. http://dx.doi.org/10.2307/1313099.

RAJ, N. and AZEZ, P.A. Spatial and temporal variations in surface water chemistry of a tropical river, the river Bharathapuzha, India. Current Science, 2009, 96(2), 245-251.

RANDALL, G.W. and MULLA, D.J. Nitrate nitrogen in surface waters as influenced by climatic conditions and agricultural practices. Journal of Environmental Quality, 2001, 30(2), 337-344. http://dx.doi. org/10.2134/jeq2001.302337x. PMid:11285893.

ROCHA, I.P.D., HOLANDA, F.S., ARAÚJO FILHO, R.N., CASADO, A.P. and BANDEIRA, A.A. Meteorological and hydrological variables on occurrence of riverbank erosion along lower São Francisco river. Revista Brasileira de Engenharia Agricola e Ambiental, 2013, 17(2), 137-144. http:// dx.doi.org/10.1590/S1415-43662013000200004.

SALOMONI, S.E., ROCHA, O. and LEITE, E.H. Limnological characterization of Gravataí, Rio Grande do Sul State, Brazil. Acta Limnologica Brasiliensia, 2007, 19(1), 1-14.

SANTIAGO, M.P., PASSAVANTE, J.Z.O. and SILVA-CUNHA, M.G.G. Caracterização de parâmetros físicos, químicos e biológicos em ambiente hipersalino, estuário do rio Pisa Sal (RN). Tropical Oceanography, 2005, 33(1), 39-55.

SIGNORIM, M., PEREIRA FILHO, J., DELFIM, R. and SCHETTINI, C.A.F. Hidrodinâmica e nutrientes inorgânicos dissolvidos no estuário do rio Perequê (SC). Brazilian Journal of Aquatic Science and Technology, 2010, 14(2), 13-21. http://dx.doi. org/10.14210/bjast.v14n2.p13-21.

SILVA, D.F., GALVÍNCIO, J.D. and ALMEIDA, H.R.R.C.A. Variabilidade da qualidade de água na bacia hidrográfica do Rio Sáo Francisco e atividades antrópicas relacionadas. Qualit@s Revista Eletrônica, 2010, 9(3), 5-17.

SILVA, D.F., GALVÍNCIO, J.D., SILVA, D.F. and ALMEIDA, H.R.R.C.A. Análise espaço-temporal de parâmetros de qualidade da água no Alto São Francisco e sua relação com intervenções antrópicas. Engenharia Ambiental-Espirito Santo do Pinhal, 2009, 14(2), 492-518.

SOUZA, W.F.L. and KNOPPERS, B.A. Fluxos de água e sedimentos na costa leste do Brasil: relaçóes entre a tipologia e as pressōes antrópicas. Geochimica Brasiliensis, 2003, 17(1), 57-74.

STRICKLAND, J.D.H. and PARSONS, T.R. A practical handbook of seawater analysis. Ottawa: Bulletin Fisheries Research Board of Canada, 1972, 167 p.

TUCCI, C.E.M. Modelos hidrológicos. Porto Alegre: UFRGS, 2000, $678 \mathrm{p}$.

TUNDISI, J.G. and MATSUMURA-TUNDISI, T. Limnologia. São Carlos: Oficina de Textos, 2008, $632 \mathrm{p}$.

TUNDISI, J.G. Reservatórios como sistemas complexos: teoria, aplicaçóes e perspectivas para usos múltiplos. In R. HENRY, ed. Ecologia de reservatórios: estrutura, função e aspectos sociais. Botucatu: FUNDIBIO/ FAPESP, 1999, p. 19-38.

WESTON, N.B., VILE, M.A., NEUBAUER, S.C. and VELINSKY, D.J. Accelerated microbial organic matter mineralization following salt-water intrusion into tidal freshwater marsh soils. Biogeochemistry, 2011, 102(1-3), 135-151. http://dx.doi.org/10.1007/ s10533-010-9427-4.

Received: 30 November 2015 Accepted: 12 May 2016 